Összefoglaló / Továbbképző közlemény - Review / Educational article

Juhász Attila',2, Nagy Csilla',2, Lomen Mihály², Nagy Attila²,3, Papp Zoltán², Gál Veronika², Oroszi Beatrix ${ }^{2}$

'Budapest Fóváros Kormányhivatala, Népegészségügyi Föosztály - Department of Public Health, Government Office of Capital City Budapest, Budapest

${ }^{2}$ Nemzeti Népegészségügyi Központ - National Public Health Center, Budapest

${ }^{3}$ Debreceni Egyetem, Népegészségügyi Kar - University of Debrecen, Faculty of Public Health, Debrecen

\title{
A Népegészségügyi Elemzési Központ Információs Rendszere (NEKIR), 2020.
}

\section{Information System of Public Health Analysis Centre (NEKIR), 2020}

\section{Összefoglalás}

A népegészségügy, valamint az egészségpolitika számára egyre nagyobb jelentőséggel bír az egészségi állapot összetevőinek, azok térbeli eloszlásának vizsgálata, a befolyásoló tényezőkből eredő kockázatok becslése, a betegségek és kockázatok térbeli összefüggésének elemzése, továbbá a magas megbetegedési/halálozási kockázatú lakosságok azonosítása, mivel lehetővé teszi célzott, hatékony népegészségügyi intervenciók megvalósítását.

Egy adott területen élő lakosság egészségi állapotának feltérképezéséhez a leíró epidemiológia módszertanával nyert információk ismerete képezi a kiindulási pontot. Ezen információk segítségével készített „területi helyzetképek, profilok" által meghatározhatók nemcsak az adott lakosság körében létező egészségproblémák, betegségterhek, hanem elvégezhető ezen problémák pri- 
orálása is aszerint, hogy mely beavatkozásoktól várható a legnagyobb egészségnyereség. A meghatározott prioritásoknak megfelelően, a „népegészségügyi” szükségletek mentén jól tervezhetők a lakosság körében a célzott, racionalizált egészségfejlesztési programok, beavatkozások.

A Népegészségügyi Elemzési Központ Információs Rendszere (továbbiakban: NEKIR) létrejöttének elsődleges célja az volt, hogy a leíró (ezen belül a tér-) epidemiológia egységes, nemzetközileg elfogadott módszertana segítségével alapvető információkat nyújtson összehasonlítható indikátorok segítségével a magyar népesség egészségi állapotáról, és az azt befolyásoló tényezőkről különböző területi felbontású szinteken a helyi, népegészségügyi, egészségfejlesztési, vagy akár egyetemi szakemberek, egészségpolitikusok számára. A NEKIR rendszer a Magyarországon rendszeresen gyüjtött adatok egységes feldolgozásával, ábrázolásával és azok felhasználóbarát hozzáférhetővé tételével szolgálja a fertőző és nem fertőző betegségekből származó legnagyobb betegségterhek csökkentését, valamint az egyenlőtlenségeket országos és helyi szinteken egyaránt.

Kulcsszavak: epidemiológiai monitorozás, népegészségügyi informatika, egészségi állapot mutatói, térepidemiológia, Bayes-statisztika, egészségpolitika

\section{Abstract}

Investigation of health determinants, their spatial distribution, the estimation of risks and the association between risks and health outcomes, and also the identification of populations at high health risk are of increasing importance for public health and health policy to design targeted, effective public health interventions.

Information gathered using descriptive epidemiological methods is an important first step in studying the population's health status. Maps and lo- 
cal profiles created by these methods will contribute not just to identifying health-related problems and disease burdens but also to prioritize them according to which interventions can deliver the greatest health gains. By this prioritizing targeted, rationalized health promotion programs can be planned and different public health needs can also be taken into account.

The primary goal of creating NEKIR (an acronym for "Information System of Public Health Analysis Centre") was to provide detailed information on health status and the distribution of associated risk factors in the Hungarian population, based on comparable indicators, using standardized descriptive (mainly spatial-) epidemiological methods. Ready-made maps and reports were prepared on different spatial resolutions to facilitate decision making and to provide support in health promotion and education as well. To fulfil the aforementioned aim different types of focused surveillance or administrative program, data (that are mainly routinely collected data) were used, processed, mapped, and made available user friendly to public health workers and decision makers. With this content NEKIR system serves informed decision making to reduce the greatest disease burden from both communicable and non-communicable diseases as well as inequalities at both national and local level.

Keywords: epidemiologic monitoring, public health informatics, health status indicators, spatial epidemiology, Bayesian approach, health policy 


\section{EGÉSZSÉGTUDOMÁNY}

2020;64(3): 51-84

HEALTH SCIENCE

Közlésre érkezett: 2020. augusztus 10.

Submitted: 10 August 2020

Elfogadva: 2020. augusztus 24.

Accepted: 24 August 2020

Levelezési cím/Correspondence:

$$
\text { Nagy Csilla }
$$

Budapest Főváros Kormányhivatala

Népegészségügyi Főosztály

1138 Budapest Váci út 174.

E-mail: nagy.csilla@nfo.bfkh.gov.hu

\section{Bevezetés}

A magyar lakosság Európai Uniós átlaghoz viszonyított, aggasztóan kedvezőtlen halálozási viszonyai régóta ismertek, melyről epidemiológiai elemzések sora szolgáltat evidenciákat'. A hazai halálozási viszonyokat alapvetően a krónikus nem fertőző betegségek határozzák meg, azonban e betegségek nem pusztán a halálozásban betöltött vezető szerepük mi- att kapnak nagy hangsúlyt, hanem meghatározó társadalmi/gazdasági szerepük miatt is. Például a korai (65 éves életkor előtt bekövetkező) megbetegedések a munkaképes korú lakosságot sújtják, ráadásul a munkából való kiesésen, illetve az életminőségbeli romláson túl sokszor a családtagokra is terhet rónak, így a betegségek direkt (pl. kezelés költsége) és indirekt (pl. táppénz) költségvonzataival társadalmi szinten egyaránt számolni kell². 2015-ben a magyar népesség születéskor várható átlagos élettartama mintegy 6 évvel volt alacsonyabb a fejlettebb Európai Uniós országok átlagánál (továbbiakban: EU15-átlag). Szomorúbb a kép, ha nemenként tekintjük ezt a mutatót, mert így 7 év a magyar férfiak lemaradása az EU15 átlagával szemben. A munkaképes korú magyar népesség halálozása 100.000 före vetítve pedig a férfiak és nők körében egyaránt közel kétszer akkora volt, mint az EU15 országokban². A lakosság egészségi állapotát leíró mutatók több irányból befolyásolhatók lehetnek: a hatékony, célzott megelőzésen túlmenően például az időben igénybe vett, megfelelő egészségügyi ellátással is ${ }^{3,4}$. 
A lakosság egészségének javítása érdekében a népesség egészségi állapotának pontos, részletes ismerete nélkülözhetetlen, akár országos, akár különböző területi szinteken tekintjük azt. Ehhez a lakosság egészségi állapotának szakmai, tudományos bizonyítékokon alapuló, egységes módszertan szerinti elemzését tartalmazó központi információs rendszer kialakítása és működtetése elengedhetetlen. E célt szolgálta a Népegészségügyi Elemzési Központ Információs Rendszere (továbbiakban: NEKIR) létrehozása ${ }^{5}$. A rendszer - a teljes magyar népességre vonatkozóan - több témakörben (modulban) tartalmaz alapvető információkat, melyeket a Magyarországon rendszeresen (rutinszerüen) gyűjtött adatok szakszerü, egységes (nemzetközi elvárásoknak megfelelő módszertannal történő) feldolgozásával, összehasonlítható indikátorok képzésével, térbeli és időbeli ábrázolásával és azok hozzáférhetővé tételével szolgáltat a felhasználóknak5.

A NEKIR célfelhasználók köre minisztériumi/országos hatáskörü intézeti, kormányhivatali, egészségfejlesztési
(Egészségfejlesztési Irodák), egyetemi, területi/iskolavédőnői, területen dolgozó népegészségügyi, egészségfejlesztési szakemberek, epidemiológusok, továbbá olyan praxisközösségek, amelyek ellátási területe egy-egy teljes járásra terjed ki.

A NEKIR-ből származó információk elősegíthetik a népegészségügyi beavatkozások eredményességének és hatékonyságának javítását, mivel a felmerülő egészségkockázatok és problémák korai felismerése révén célzott beavatkozásra nyílhat lehetőség. A NEKIR támogatja ágazati és interszektoriális szinten az egészségpolitikai döntéshozatalt, az országos és a helyi szintű egészségpolitikai stratégiák, programok, egészségtervek megalapozását, a tervezés és beavatkozás fókuszának és eredményességének javítását. Mindezek eredményeképpen a lakosság egészségi állapota érdemben javulhat. 


\section{A NEKIR bemutatása}

\section{Indikátorok, adatforrások}

A NEKIR alappillére a rendszeresen gyüjtött, egészségi állapotot leíró és/vagy azt befolyásoló adatok becsatornázása és tudományos igényességű feldolgozása.

A lakosság egészségi állapotát és az azt befolyásoló tényezőket különböző egészségi állapotbeli indikátorok segítségével jellemezzük. A NEKIR-ben indikátorként, indikátor csoportokként olyan paraméterek szerepelnek, amelyek egyrészt hozzáférhetők, továbbá információt nyújtanak egy egészségi állapotot jellemző, vagy azzal kapcsolatba hozható jelenség, a környezet, vagy egyéb egészséget meghatározó tényező állapotáról. Olyan indikátorokat is tartalmaz az információs rendszer, amelyek segítséget nyújthatnak annak megítéléséhez is, hogy milyen közel jutottunk adott egészségpolitikai célok eléréséhez ${ }^{6}$.

A nemzetközi összehasonlíthatóság érdekében az Alapvető Európai Egészségügyi Mutatók (European Core
Health Indicators - ECHI) rendszerét alapul véve alakítottuk ki az általunk felhasználni kívánt indikátorok listáját ${ }^{8} . A z$ ECHI szempontrendszer alkalmazása mellett szólt, hogy ebben a rendszerben rendelkezésre álltak a szükséges fogalom meghatározások és adatgyűjtési mechanizmusok, valamint lehetséges különböző jellemzők mentén (pl. nem, életkor, területi egység) a mutatók részletesebb vizsgálata.

Az általunk felhasználásra kerülő indikátorok kiválasztása során több szempontot vettünk figyelembe. Első lépésként a SMART (Specific (egyedi), Measurable (mérhető), Achievable (megvalósítható), Realistic (reális) és Time-based (időtartamhoz kötött) kritériumoknak való megfelelést vettük alapul. Mindegyik kiválasztott indikátorra jellemző, hogy specifikus, mérhető, megvalósítható, lényeges és időalapú ${ }^{8}$. Indikátor kizárási kritériumként jellemzően a validitás szerepelt: alacsony vagy nem kellően megítélhető érvényesség esetén az indikátor nem szerepel a rendszerben. 
Az ECHI szisztéma keretrendszert adott, vagyis a NEKIR-ben jelenleg szereplő indikátorok listája a szakirodalom ajánlásait $6,7,8$, valamint nem utolsó sorban - az adatok meglétét, elérhetőségét figyelembe véve alakult ki.

A NEKIR-ben jelenleg fellelhető indikátorok alapjául szolgáló adatok forrásai az alábbiak:

- Központi Statisztikai Hivatal (KSH);

- Országos Területfejlesztési és Területrendezési Információs Rendszer;

- Nemzeti Rákregiszter és Biostatisztikai Központ;

- Országos Gyermek Onkológiai Regiszter;

- Belügyminisztérium Nyilvántartások Vezetéséért Felelős Helyettes Államtitkársága.

\section{A NEKIR tartalma}

A NEKIR-ben több témakörben (modulokban), időszakban és felbontási szinten hozzáférhetők az információk.
Az alábbi témakörök szerint (modulokban) csoportosítottuk a mutatókat:

1) Halálozási adatok;

2) Rosszindulatú daganatos megbetegedési adatok;

3) Népmozgalmi adatok;

4) Népszámlálás 2011.

\section{Halálozási adatok}

A halálozási adatok esetében 26 betegség/betegségcsoport szerinti halálozási adatok és térképek tölthetők le a teljes lakosság (0-x évesek), a 25-64 éves és a 65 éves és idősebb korcsoportú népességre vonatkozóan (1. táblázat).

\section{Az alkoholfogyasztással össze-} függésbe hozható halálokok csoportjának képzésekor a WHO Health for All (WHO HFA) adatbázisának a meghatározását vettük figyelembe ${ }^{\text {I }}$ gy a következő halálokok tartoznak e csoportba: a nyelőcső rosszindulatú daganata (C15), a gége rosszindulatú daganata (C32), alkohol okozta mentális- és viselkedészavarok (F10), alkoholos májbetegség (K70), idült májgyulladás (K73), májfib- 
rosis és májzsugorodás (K74), egyéb májbetegségek (K76), erőszakos (külső ok szerinti) halálokok (V01-Y99).

Szintén a WHO HFA Adatbázis meghatározását vettük alapul a dohányzással összefüggésbe hozható halálozás esetében², melybe így a következő halálokok tartoznak: ajak, szájüreg és garat rosszindulatú daganata (COO-C14), a gége, a légcső, a hörgők és a tüdő rosszindulatú daganata (C32-C34), nyelőcső rosszindulatú daganata (C15), ischaemiás szívbetegségek (120-125), agyérbetegségek (160-169), idült alsó légúti betegségek (J40-J47).

Az elsődleges megelözéssel befolyásolható, elkerülhető halálozás (EMB) csoportjába tartozónak tekintettük azokat a - nemzetközi referenciák szerint meghatározott - 75 év alatt bekövetkező haláleseteket, melyek megelőzésére rendelkezünk bizonyítékokon alapuló, hatékony, elsősorban központi, széles körben szervezett (populációs szintű) primer prevenciós módszerekkel. Ezen módszerek alkalmazására irányuló céltudatos egészségpolitikai, népegészségügyi döntések, beavatkozások révén ezek a halálozások jelen tudásunk mellett jelentősen befolyásolhatók, illetve elkerülhetők ${ }^{9,10,11}$.

\section{Az egészségügyi ellátáshoz köt-} hetö, elkerülhetö halálesetek azok a halálesetek, melyek meghatározott életszakaszban, az egészségügyi beavatkozások időben történő, megfelelő igénybevételével és alkalmazásával elkerülhetők lennének ${ }^{9,10,11}$. 


\section{1. táblázat: NEKIR „Halálozás adatok” moduljában alkalmazott betegségek/betegségcsoportok a vizsgált korcsoportokkal, 2020.}

Table 1. Diseases/disease groups applied in the "Mortality Data" module of NEKIR with the examined age groups, 2020.

\begin{tabular}{|c|c|c|}
\hline Betegségcsoport & BNO-10. & Korcsoport \\
\hline Általános halálozás & A00-Y98 & $\begin{array}{l}0,0-x, 1-14,15- \\
24,25-64,65-x\end{array}$ \\
\hline Keringési rendszer betegségei & $100-199$ & $0-x, 25-64,65-x$ \\
\hline $\begin{array}{l}\text { Magas vérnyomás és az } \\
\text { agyér betegségek }\end{array}$ & 170-115, 160-199 & $0-x, 25-64,65-x$ \\
\hline Ischaemiás szívbetegségek & $120-125$ & $0-x, 25-64,65-x$ \\
\hline Heveny szívizomelhalás & $127-122$ & $0-x, 25-64,65-x$ \\
\hline Rosszindulatú daganatok & $\mathrm{COO}-\mathrm{C} 97$ & $0-x, 25-64,65-x$ \\
\hline $\begin{array}{l}\text { Az ajak, szájüreg és a garat } \\
\text { rosszindulatú daganata }\end{array}$ & $\mathrm{COO}-\mathrm{C} 14$ & $0-x, 25-64,65-x$ \\
\hline $\begin{array}{l}\text { A vastagbél, végbél és } \\
\text { az anus rosszindulatú } \\
\text { daganatai }\end{array}$ & $\mathrm{C} 18-\mathrm{C} 21$ & $0-x, 25-64,65-x$ \\
\hline $\begin{array}{l}\text { A légcső, a hörgő és tüdő } \\
\text { rosszindulatú daganata }\end{array}$ & C33-C34 & $0-x, 25-64,65-x$ \\
\hline $\begin{array}{l}\text { A bör rosszindulatú } \\
\text { melanomája }\end{array}$ & $\mathrm{C} 43$ & $0-x, 25-64$ \\
\hline Mesothelioma & C45 & $0-x$ \\
\hline $\begin{array}{l}\text { Az emlő rosszindulatú } \\
\text { daganata }\end{array}$ & C50 & $0-x, 25-64,65-x$ \\
\hline $\begin{array}{l}\text { A méhnyak rosszindulatú } \\
\text { daganata }\end{array}$ & C53 & $0-x, 25-64,65-x$ \\
\hline $\begin{array}{l}\text { A prosztata rosszindulatú } \\
\text { daganata }\end{array}$ & C61 & $0-x, 25-64,65-x$ \\
\hline A légzőrendszer betegségei & J00-J99 & $0-x, 25-64,65-x$ \\
\hline $\begin{array}{l}\text { Idült alsó légúti } \\
\text { betegségek }\end{array}$ & $\mathrm{J} 40-\mathrm{J} 47$ & $0-x, 25-64,65-x$ \\
\hline $\begin{array}{l}\text { Az emésztőrendszer } \\
\text { betegségei }\end{array}$ & KOO-K93 & $0-x, 25-64,65-x$ \\
\hline $\begin{array}{l}\text { Alkoholos májbetegségek } \\
\text { és májzsugor }\end{array}$ & K70 & $0-x, 25-64,65-x$ \\
\hline $\begin{array}{l}\text { A morbiditás és mortalitás } \\
\text { külső okai }\end{array}$ & V01-Y98 & $0-x, 25-64,65-x$ \\
\hline Balesetek & V01-X59 & $0-x, 25-64,65-x$ \\
\hline Közlekedési balesetek & V01-V99 & $0-x, 25-64,65-x$ \\
\hline Esések & WoO-W19 & $0-x, 25-64,65-x$ \\
\hline Öngyilkosság & X60-X84 & $0-x, 25-64,65-x$ \\
\hline
\end{tabular}




\begin{abstract}
Alkoholfogyasztással összefüggésbe hozható halálozás
\end{abstract}

Dohányzással összefüggésbe hozható halálozás

Elsődleges megelőzéssel befolyásolható, elkerülhető halálozás

\section{Az egészségügyi szolgáltatáshoz köthető, elkerülhető halálozás}

\section{Elsődleges megelőzéssel} befolyásolható, elkerülhetô halálozás (OECD/Eurostat 2019. indikátorlista)

\section{Elsődleges megelőzéssel} befolyásolható, elkerülhető halálozás (OECD/Eurostat

2019. indikátorlista) $20-x, 25-64,65-x$

A halálozási adatok esetében 20 db megyei, 197 db járási adatbázis (táblázatos formában, „profilként”), illetve 3.358 térkép tölthető le, országos térképek megyei, járási és települési felbontásban, valamint megyei térképek járási felbontásban (7-2. ábra). A rosszindulatú daganatos megbetegedési adatok esetében 20 db megyei, 197 db járási adatbázis (szintén táblázatos formában, „profilként”), valamint 989 térkép hozzáférhető (1., 3. ábra). 


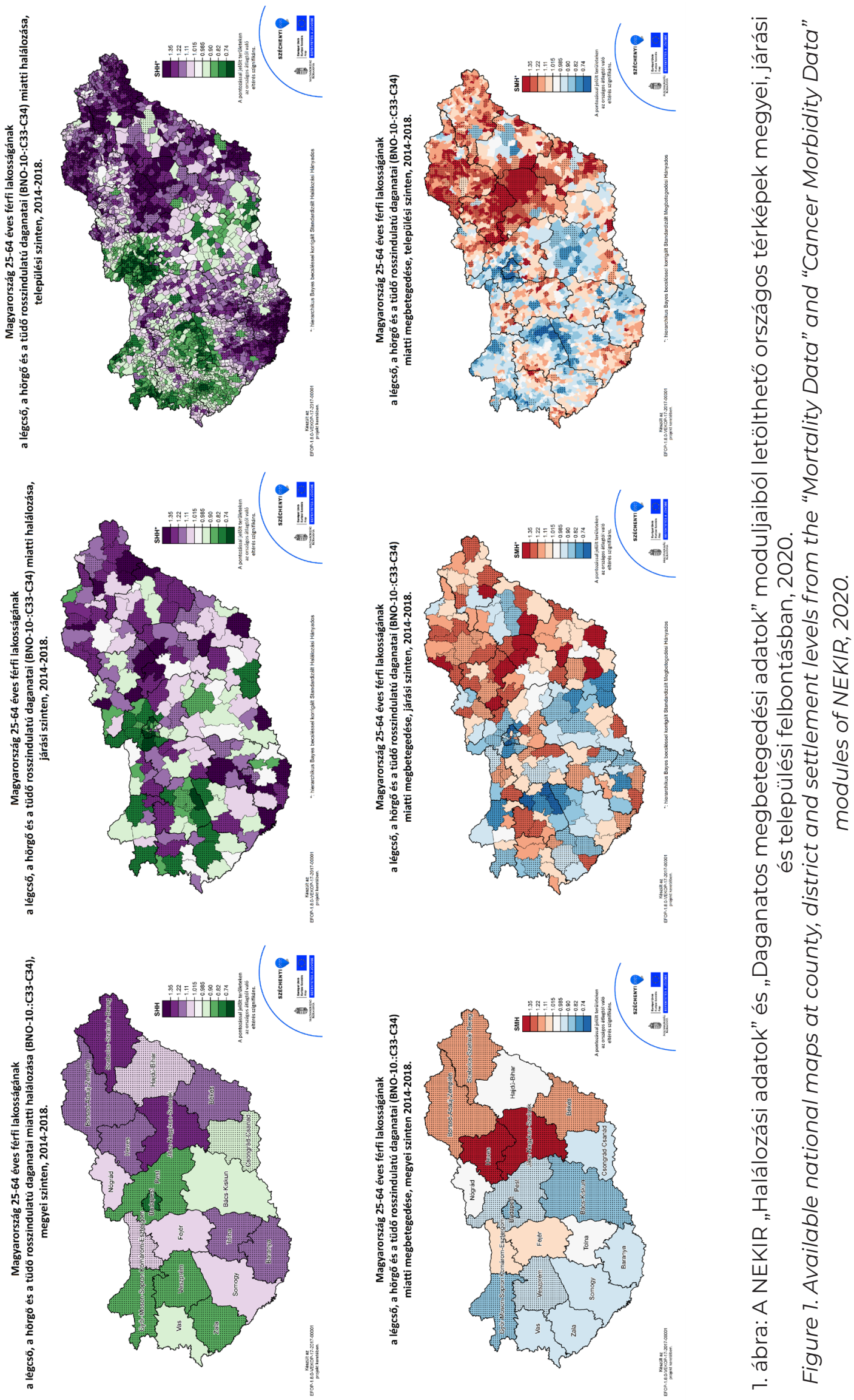



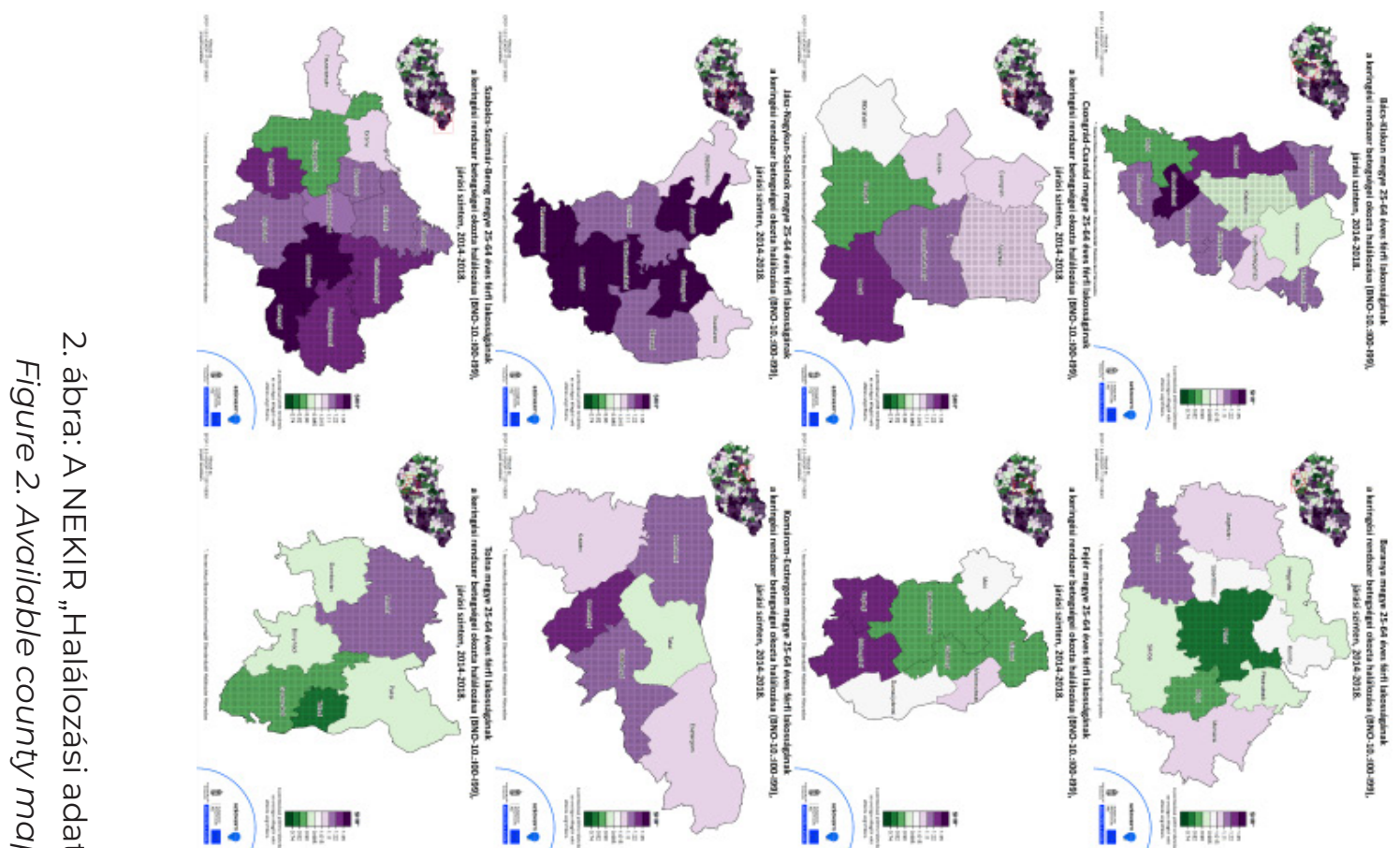

i.) Han: Hi.j)

1. Hin:

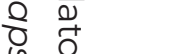

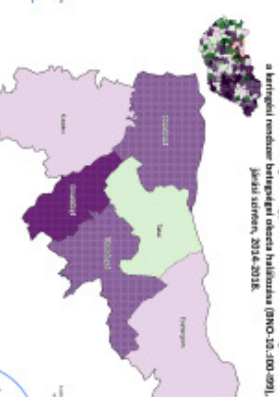

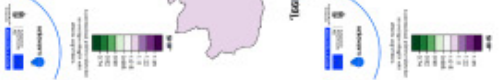

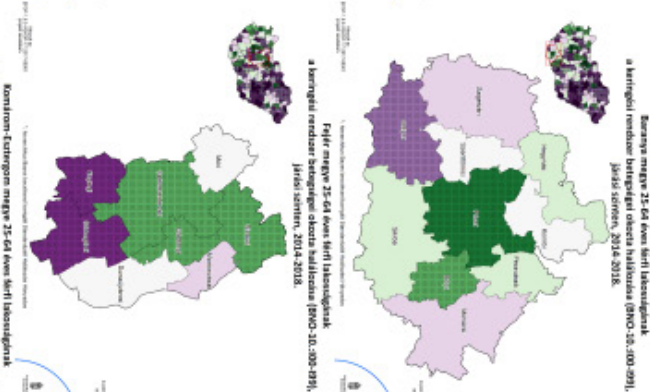

Q

․․․

$\stackrel{\mathrm{O}}{\underline{\mathrm{n}}}$

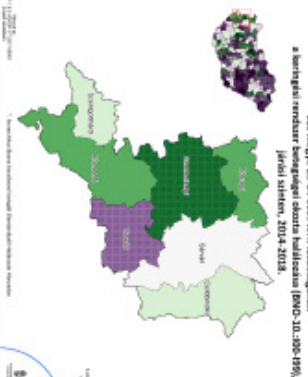

ii.) Hain:

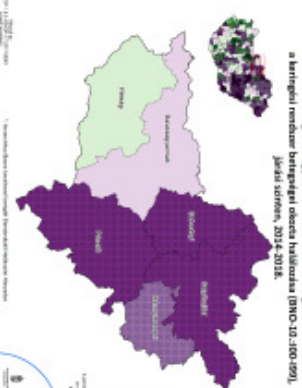

i.j)

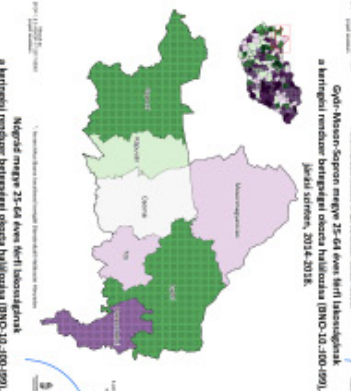

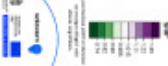

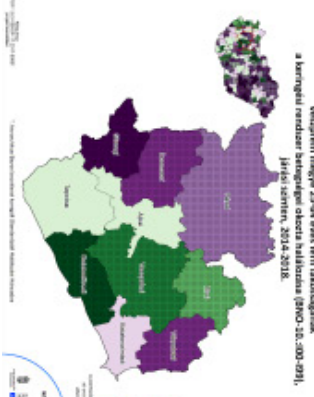

i.i.) Hitis:

i.j)

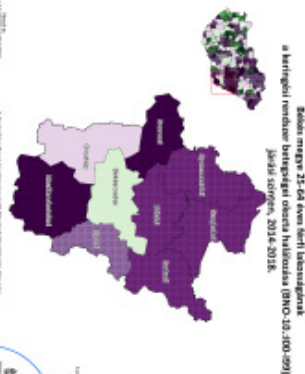

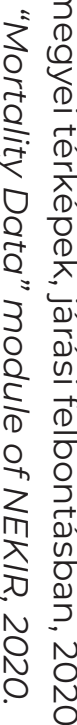
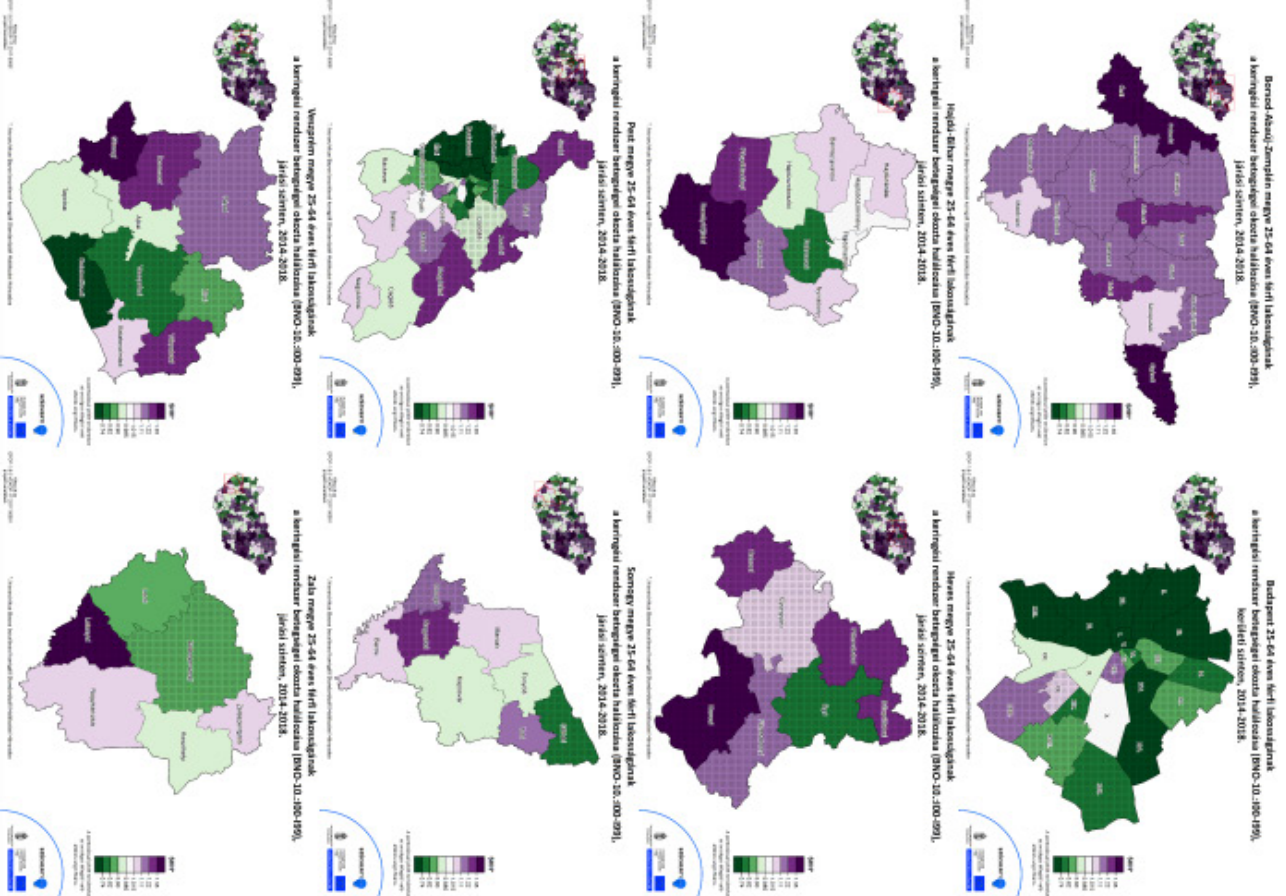
Összefoglaló / Továbbképző közlemény - Review / Educational article

2. táblázat: A NEKIR „Daganatos megbetegedési adatok" moduljában alkalmazott betegségek/ betegségcsoportok a vizsgált korcsoportokkal, 2020.

Table 2. Diseases/disease groups applied in the "Cancer Morbidity Data" module of NEKIR with the examined age groups, 2020.

\begin{tabular}{|c|c|c|}
\hline Betegségcsoport & BNO-10. & Korcsoport \\
\hline Rosszindulatú daganatok & CoO-C97 & $0-x, 25-64,65-x$ \\
\hline Az ajak, szájüreg és a garat rosszindulatú daganata & $\mathrm{COO}-\mathrm{Cl} 4$ & $0-x, 25-64,65-x$ \\
\hline A vastagbél, végbél és az anus rosszindulatú daganatai & $\mathrm{C} 18-\mathrm{C} 21$ & $0-x, 25-64,65-x$ \\
\hline A légcső, a hörgő és tüdő rosszindulatú daganata & C33-C34 & $0-x, 25-64,65-x$ \\
\hline A bőr rosszindulatú melanomája & $\mathrm{C} 43$ & $0-x, 25-64$ \\
\hline Mesothelioma & C45 & $0-x$ \\
\hline Az emlő rosszindulatú daganata & $\mathrm{C} 50$ & $0-x, 25-64,65-x$ \\
\hline A méhnyak rosszindulatú daganata & C53 & $0-x, 25-64,65-x$ \\
\hline A prosztata rosszindulatú daganata & c61 & $0-x, 25-64,65-x$ \\
\hline
\end{tabular}

3. táblázat: A NEKIR „Daganatos megbetegedési adatok" moduljában a gyermekkorú lakosság esetében alkalmazott rosszindulatú daganatos betegségek/betegségcsoportok, 2020.

Table 3. Diseases/disease groups applied in the "Cancer Morbidity Data" module of NEKIR in childhood age group, 2020.

\begin{tabular}{ccc}
\multicolumn{1}{c}{ Betegségcsoport } & BNO-10. & Korcsoport \\
Daganatok & COO-D48 & $0-14$ \\
Leukémia & C90-C95 & $0-14$
\end{tabular}

Az agy és más központi idegrendszeri C71-72,C75.2,C75.3,D33,D43,D44.5 tumorok

0-14

Egyéb tumorok

$0-14$ 


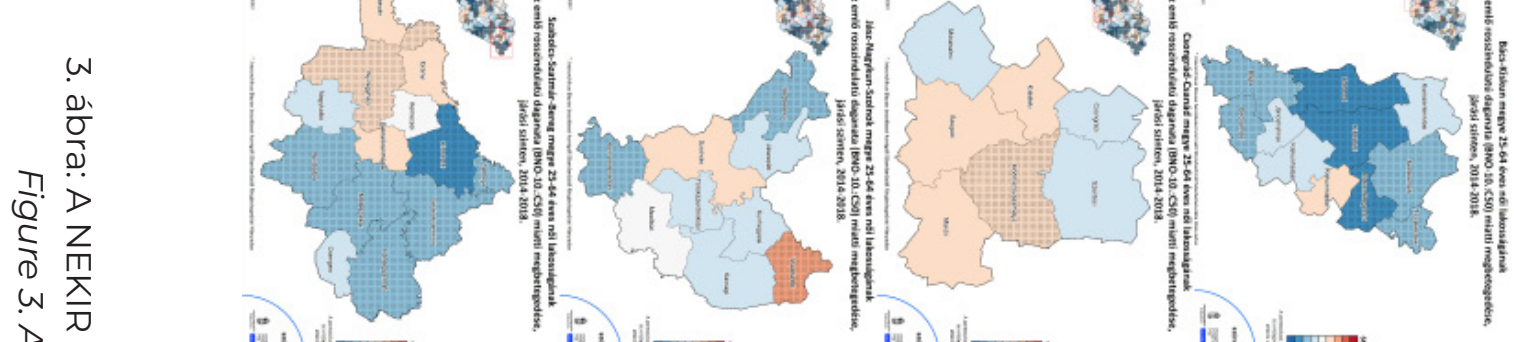

$\stackrel{D}{\Sigma}$

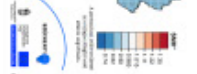

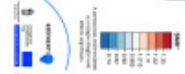

1.1. Ham

1.6) ||

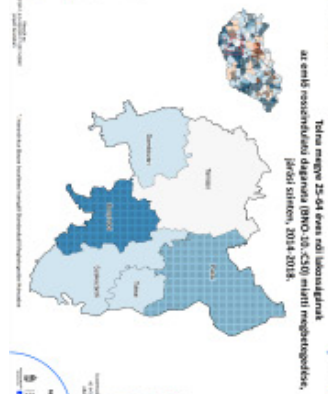

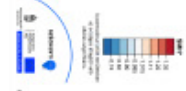

1.1.) Ham

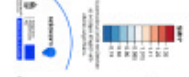

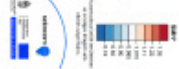

․․․

․ำ

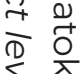

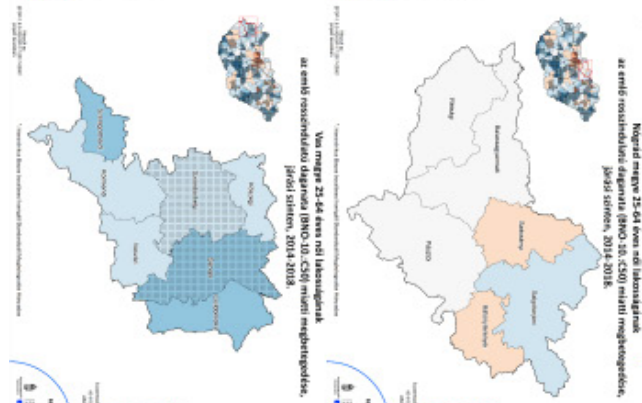

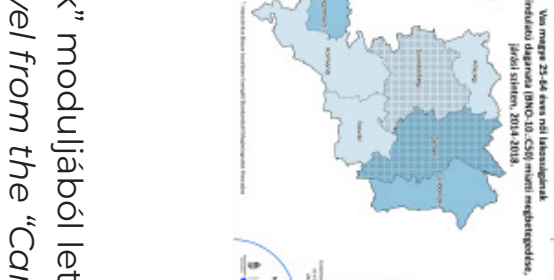

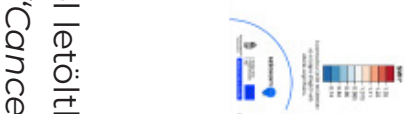

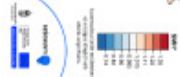

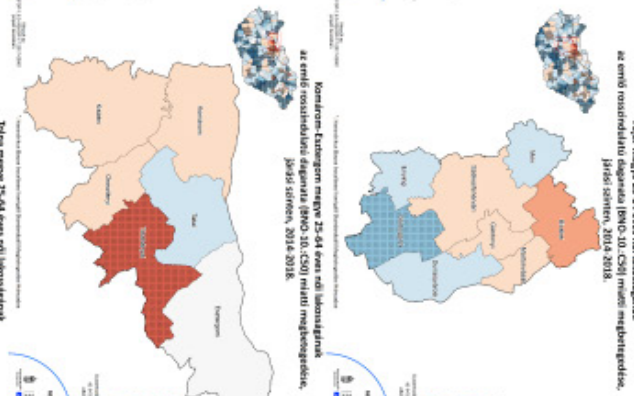

उ $\stackrel{\mathbb{1}}{0}$

ㅎ. 3

욜

$\square$ D

Q

$3 \frac{D}{0}$

ㅇำ

市
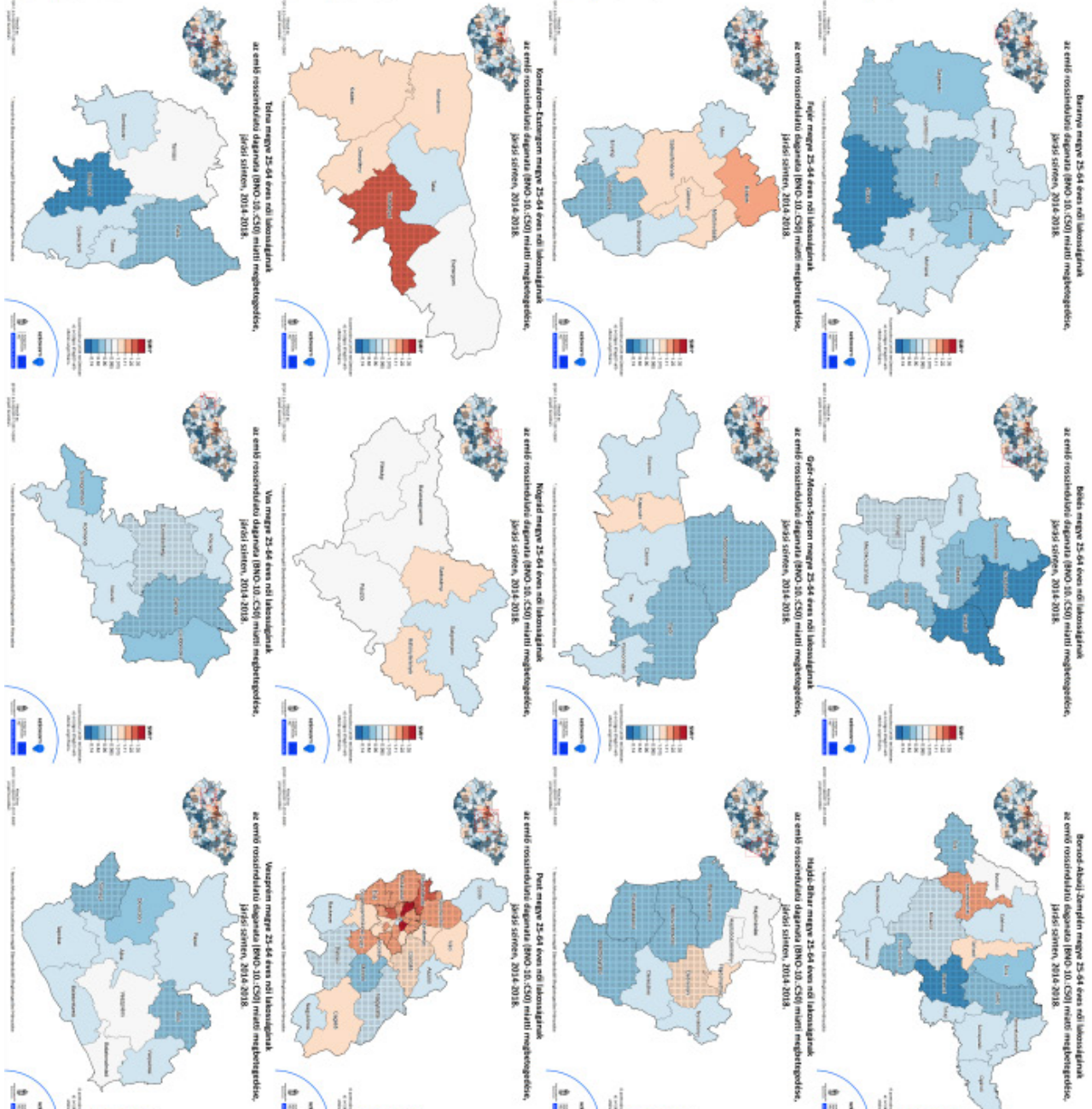

II.

ii.) Hat

|i.)

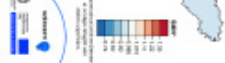

$\rightarrow \underline{\omega}$

$\sum \vec{D}$

증

$N$ 只

$\begin{array}{ll}0 & n \\ 0 & 0 \\ 0 & 0\end{array}$

กิ

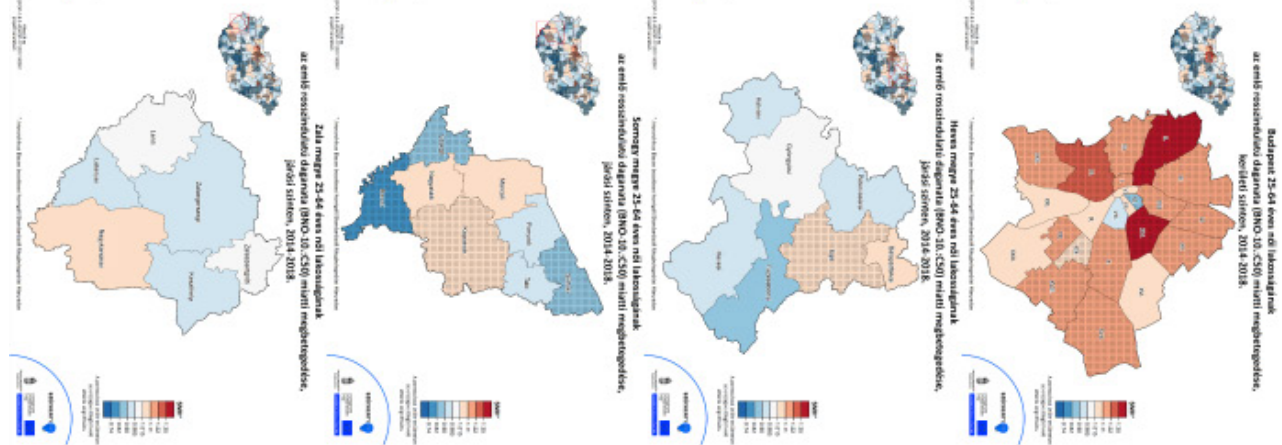




\section{Népmozgalmi adatok}

A népmozgalmi adatok segítségével a felhasználók adott megye vagy járás lakosságának demográfiai helyzetét elemezhetik (4. táblázat).

\section{Népszámlálás 2011.}

A 2011. évi Népszámlálás adatai és térképei segítenek a megyei, járási és te- lepülési lakosságok társadalmi-gazdasági helyzetének elemzésében (például az iskolai végzettség, a családi állapot, a családok szerkezete), továbbá a lakókörnyezet egyes jellemzőiről is lehet tájékozódni a térképek és az indikátorok segítségével (5. táblázat).

\section{4. táblázat: A NEKIR „Népmozgalom" modulban alkalmazott indikátorok és epidemiológiai mu- tatók, 2020. \\ Table 4. Epidemiological indicators used in the "Demographical changes" module of NEKIR, 2020.}

\section{Népmozgalmi mutató}

Csecsemőhalálozási arányszám 1000 före

Élveszületési arányszám 1000 före (nyers)

Halálozási arányszám 1000 före (nyers)

Természetes szaporodás-fogyás arányszáma 1000 före

Belföldi vándorlási különbözet 1000 före

\section{Definíció}

Ezer élveszülöttre jutó egy éven aluli elhunyt. (csecsemőhalálozás: az élve születést követően, az egyéves kor betöltése előtt bekövetkezett halálozás. A halvaszülött és a születésének évfordulóján meghalt gyermek nem tartozik bele a csecsemőhalálozásba).

Egy adott évi élveszületések számának a lakosság évközepi számához viszonyított aránya ezer före vetítve.

Ezer lakosra jutó halálozás, az elhunyt nemével, életkorával azonos csoportba tartozó évközepi népességre számítva.

A nyers élveszülétési és a nyers halálozási arányszám különbözete.

Egy adott közigazgatási egységbe állandó vagy ideiglenes jelleggel bejelentkezők, valamint visszavándorlók és az onnan más közigazgatási egységbe állandó vagy ideiglenes jelleggel bejelentkezők és visszavándorlók számának különbözete 1000 före vonatkoztatva. (Az adatok forrása: a belföldi vándorlási statisztika számbavételének alapja a lakcím bejelentési rendszer, amelyről a Belügyminisztérium Nyilvántartások Vezetéséért Felelős Helyettes Államtitkárság (BM NYHÁT, korábban KEKKH) szolgáltat adatállományokat statisztikai feldolgozás céljára.) 
Eltartottsági ráta

Populáció/Népesség
A gyermek- (0-14 éves) és az időskorú népesség (65-X éves) a 15-64 éves korú népesség százalékában.
Korcsoportonként és nemenként a populáció/lakosság száma 2008. és 2017. év tekintetében. Kiegészítő tábla segítségével meghatározható a 18 éven aluli és felüli populáció nagysága is.

A demográfiai/népmozgalmi adatok vonatkozásában 20 db megyei, 197 db járási adatbázis tölthető le, kizárólag táblázatos formában.

\section{5. táblázat: A NEKIR „Népszámlálás 2011.” modulban elérhető indikátorok és mutatók, 2020. *: Térképek elérhetök megyei, járási és települési szinten. \\ Table 5. Indicators used in the "Census 2011" module of NEKIR, 2020. *: Available maps at county, district and settlement level.}

\section{Népszámlálási mutató}

Foglalkoztatottak aránya*

Munkanélküliek aránya*

Inaktív keresők aránya*

Eltartottak aránya*

Összkomfortos lakások aránya

Komfortos lakások aránya

Összkomfortos és komfortos lakások aránya*

Félkomfortos lakások aránya

Komfort nélküli lakások aránya

Szükség- és egyéb lakások aránya

Hálózati vízvezetékkel ellátott lakások aránya

Házi vízvezetékkel ellátott lakások aránya

\section{Definíció}

A foglalkoztatottak aránya a teljes lakosság körében.

A munkanélküliek aránya a teljes lakosság körében.

Az inaktív keresők aránya a teljes lakosság körében.

Az eltartottak aránya a teljes lakosság körében

Az összkomfortos lakások (és lakott üdülők) aránya a teljes lakás (és lakott üdülő) számához viszonyítva.

A komfortos lakások (és lakott üdülők) aránya a teljes lakás (és lakott üdülő) számához viszonyítva

Az összkomfortos és komfortos lakások (és lakott üdülők) aránya a teljes lakás (és lakott üdülő) számához viszonyítva.

A félkomfortos lakások (és lakott üdülők) aránya a teljes lakás (és lakott üdülő) számához viszonyítva.

A komfort nélküli lakások (és lakott üdülők) aránya a teljes lakás (és lakott üdülő) számához viszonyítva.

A szükség- és egyéb lakások (és lakott üdülők) aránya a teljes lakás (és lakott üdülő) számához viszonyítva.

A hálózati vízvezetékkel ellátott lakások (és lakott üdülők) aránya a teljes lakás (és lakott üdülő) számához viszonyítva.

A házi vízvezetékkel ellátott lakások (és lakott üdülők) aránya a teljes lakás (és lakott üdülő) számához viszonyítva. 
Hálózati és házi vízvezetékkel ellátott lakások aránya*

Meleg folyóvízzel ellátott lakások aránya

Vízöblítéses WC-vel ellátott lakások aránya*

Közcsatornával ellátott lakások aránya*

Házi csatornával ellátott lakások aránya

Általános iskola 8. évfolyamnál alacsonyabb végzettségüek aránya*

Általános iskola 8. évfolyam végzettségüek aránya*

Középfokú iskola, érettségi nélküli végzettségüek aránya*

Érettségizettek aránya

Egyetem, föiskola stb. oklevéllel végzettségüek aránya*

Nőtlenek / hajadonok aránya*

Házasok aránya*

Élettársi kapcsolatban élők aránya

Elváltak aránya*

Özvegyek aránya*

Családra vonatkoztatott családtagok* száma 100 családra jutó családtagok száma.
A közcsatornával ellátott lakások (és lakott üdülők) aránya a teljes lakás (és lakott üdülő) számához viszonyítva.

A hálózati és házi vízvezetékkel ellátott lakások (és lakott üdülők) aránya a teljes lakás (és lakott üdülő) számához viszonyítva.

A meleg folyóvízzel ellátott lakások (és lakott üdülők) aránya a teljes lakás (és lakott üdülő) számához viszonyítva.

A vízöblítéses WC-vel ellátott lakások (és lakott üdülők) aránya a teljes lakás (és lakott üdülő) számához viszonyítva.

A házi csatornával ellátott lakások (és lakott üdülők) aránya a teljes lakás (és lakott üdülő) számához viszonyítva.

Befejezett általános iskola végzettséggel sem rendelkezők aránya 15 éves és idősebb lakosság körében.

Általános iskolával (8. évfolyam), mint legmagasabb iskolai végzettséggel rendelkezők aránya a 15 éves és idősebb lakosság körében.

Középfokú iskola érettségi nélkül, szakmai oklevéllel, mint legmagasabb iskolai végzettséggel rendelkezők aránya a 18 éves és idősebb lakosság körében.

Érettségivel, mint legmagasabb iskolai végzettséggel rendelkezők aránya a 18 éves és idősebb lakosság körében.

Egyetemi, főiskolai stb. oklevéllel, mint legmagasabb iskolai végzettséggel rendelkezők aránya a 25 éves és idősebb lakosság körében.

A nőtlenek, hajadonok aránya a 15 éves és idősebb lakosság körében.

A házasok aránya a 15 éves és idősebb lakosság körében.

Az élettársi kapcsolatban élők aránya a 15 éves és idősebb lakosság körében.

Az elváltak aránya a 15 éves és idősebb lakosság körében.

Az özvegyek aránya a 15 éves és idősebb lakosság körében. 
Családra vonatkoztatott gyermekszám

Gyermekes családok aránya*

Gyermektelen családok aránya

Házaspár és élettársi kapcsolatok*

Élettársi kapcsolatok

Gyermeket nevelő házaspár és élettársi kapcsolatok*
100 családra jutó gyermekek száma.

A gyermekes családok aránya a családok számához viszonyítva.

A gyermektelen családok aránya a családok számához viszonyítva.

A párkapcsolaton (házaspár és élettársi kapcsolat) alapuló családok aránya a családok számához viszonyítva.

Az élettársi kapcsolaton alapuló családok aránya a családok számához viszonyítva.

Agyermeket nevelő, kétszülős (házaspár és élettársi kapcsolat) családok aránya a családok számához viszonyítva.

Egy gyermeket nevelő házaspár és élettársi kapcsolatok

Egy gyermeket nevelő, kétszülős (házaspár és élettársi kapcsolat)családok aránya a családok számához viszonyítva.

Két gyermeket nevelő házaspár és élettársi kapcsolatok

Két gyermeket nevelő, kétszülős (házaspár és élettársi kapcsolat) családok aránya a családok számához viszonyítva.

Három vagy több gyermeket nevelő házaspár és élettársi kapcsolatok*

Három vagy több gyermeket nevelő, kétszülős (házaspár és élettársi kapcsolat)családok aránya a családok számához viszonyítva.

Gyermeket nevelő egyszülős családok aránya*

Egyszülős, gyermeket nevelő családok aránya a családok számához viszonyítva.

Egy gyermeket nevelő egyszülős családok aránya

Egyszülős, egy gyermeket nevelő családok aránya a családok számához viszonyítva.

Két gyermeket nevelő egyszülős családok aránya

Egyszülős, két gyermeket nevelő családok aránya a családok számához viszonyítva.

Egyszülős, három vagy több gyermeket nevelő családok aránya a családok számához viszonyítva.
Három, vagy több gyermeket nevelő egyszülös családok aránya*
A 2011. évi Népszámlálás moduljából 197 db járási adatbázis (országos, megyei és település szintú adatokkal együtt) táblázatos formában, illetve egyes választott mutatókra összesen 986 db térkép tölthető le a regisztrált felhasználók számára. A térképek elérhetők megyei, járási és települési szinten is (5. táblázat, 4. ábra). 

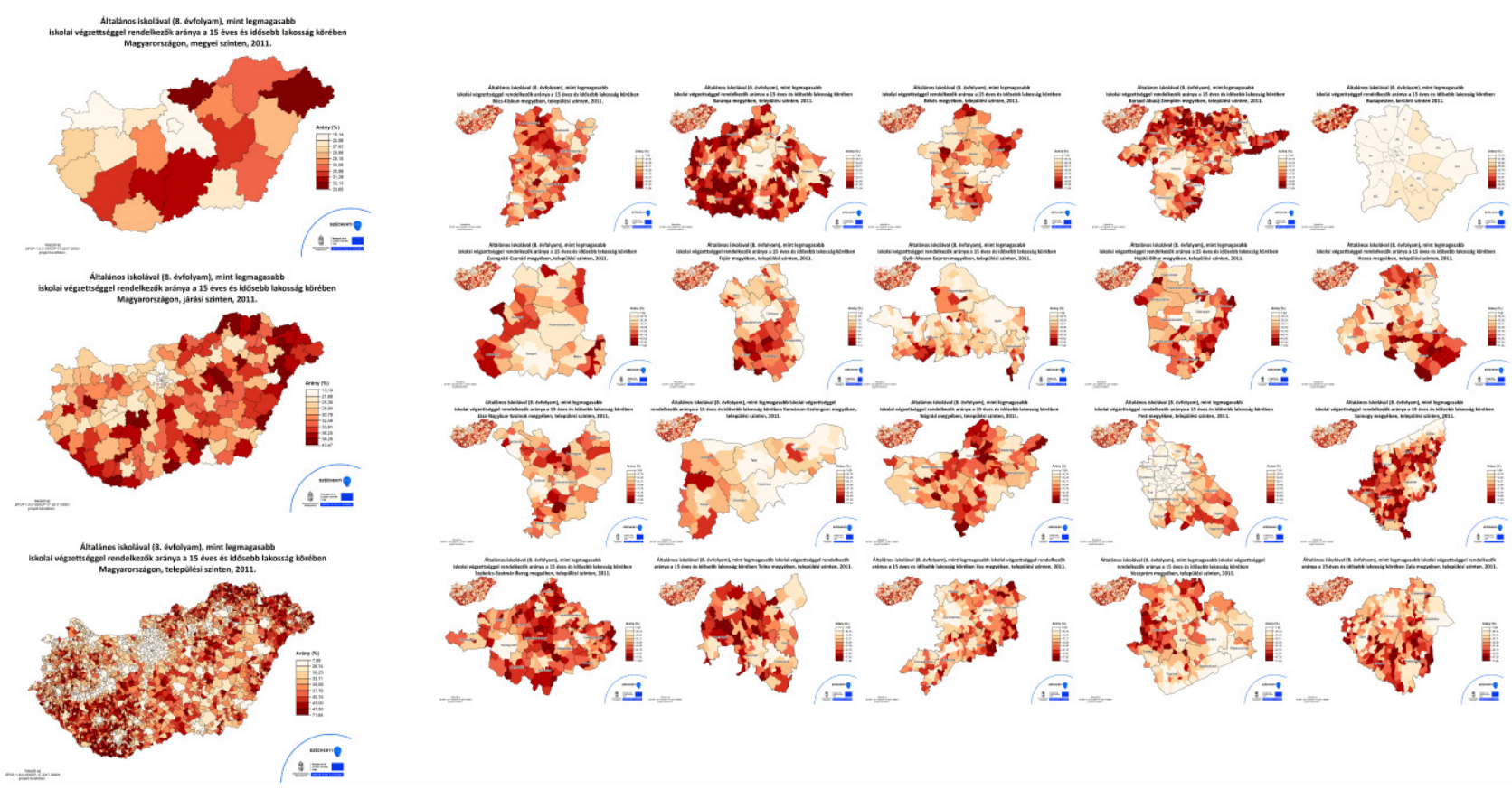

4. ábra: A NEKIR Népszámlálás 2011. moduljából letölthető országos térképek megyei, járási és települési felbontásban, valamint megyei térképek települési felbontásban, 2020.

Figure 4. Available national maps at county, district and settlement levels, additionally county maps at settlement level from the "Census 2017" module of NEKIR, 2020.

\section{Infóprofilok}

A mutatókat tartalmazó, letölthető adattáblák, térképek mellett, a gyors elemzés támogatására, megyei és járási infóprofilok is elérhetők, melyek segítésével könnyen áttekinthető egy adott megye, vagy járás lakosságának egészségi állapota, társadalmi-gazdasági helyzete, valamint az országos értékekhez való viszonya, elhelyezkedése (5. ábra). Az ábrákon a minimum, maximum értékek, valamint az országos referenciaszint (1) került feltüntetésre. Ezen a skálán helyezkedik el az adott megyére/járásra jellemző halálozási kockázat (standardizált halálozási hányados), mely megmutatja hányszorosa a megye/járás lakosságának adott halálozása az országos halálozási szinthez képest. Zöld színnel jelzi, ha az országos halálozási kockázatnál szignifikánsan alacsonyabb, lila színnel pedig, ha szignifikánsan magasabb volt a halálozás kockázat. 
Összefoglaló / Továbbképző közlemény - Review / Educational article

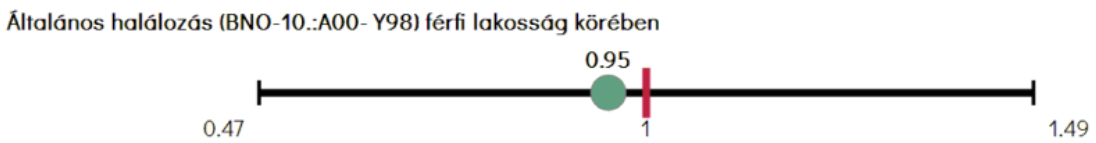

Rosszindulatú daganatok (BNO-10.:C00-C97) férfi lakosság körében

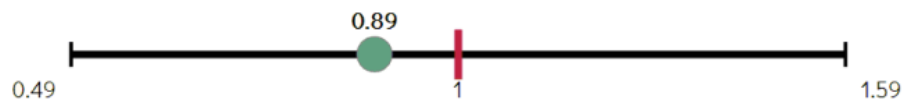

Keringési rendszer betegségei (BNO-10.:I00-I99) férfi lakosság körében

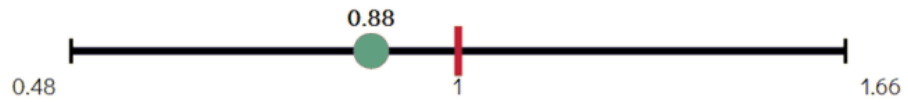

Légzổrendszer betegségei (BNO-10.:J00-J99) férfi lakosság körében

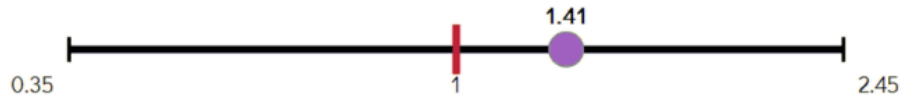

Emésztổrendszer betegségei (BNO-10.:K00-K93) férfi lakosság körében

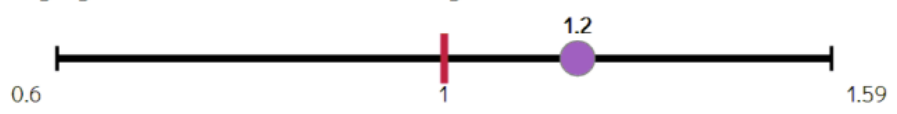

Külsô okok (BNO-10.:V01- Y98) férfi lakosság körében

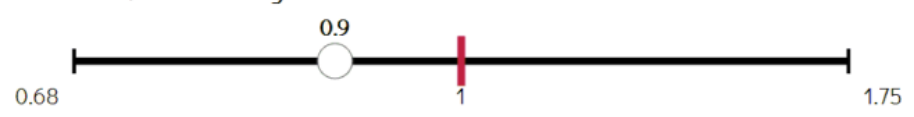

5. ábra: A NEKIR-ben található halálozási infóprofil, 2020.

Figure 5. Available info profile from the "Mortality Data" module of NEKIR, 2020.

\section{Módszertani háttér}

A NEKIR-ből letölthető adatok alapján idöbeli és területi jellegzetességek elemezhetök.

A rendszerben (aktuálisan) 20072018. közötti idöszakra vonatkozóan találhatók adatok, de ez egyes mutatók esetében ettől eltérő lehet.

\section{A területi különbségek vizsgálata}

A népszámlálás eredményeinek bemutatására alkalmazott mutatók az intenzitás viszonyszámok és a relatív hányadosok, melyek megmutatják, hogy az adott jelenség gyakorisága alacsonyabb, magasabb vagy megegyezik az országos gyakorisággal. 


\section{A halandóság és megbetegedé-} si elöfordulások területi különbségeinek vizsgálatához a direkt standardizált arányszám kis esetszámokból eredő instabilitása miatt az indirekt standardizálás módszere került alkalmazásra4 .

A halandóság/daganatos megbetegedések területi egyenlőtlenségeinek bemutatása Standardizált Hányadosok (SH) számításával történt ${ }^{4}$. Az indirekt standardizált hányados azt mutatja meg, hogy az adott terület lakosságának adott időszakra és betegségcsoportra vonatkozó halálozása/ megbetegedése hány százaléka az országos halálozási szintnek.

A halálozás/megbetegedés számok ingadozásaiból származó instabilitás csökkentése érdekében a területi különbségek vizsgálatakor több éves időtartamra összevonva végeztük az elemzést az utolsó vizsgált öt évre (2014-2018) vonatkozóan.

Az SH már stabilabb mutató a direkt standardizált arányszámnál, azonban, mivel a népesség korcsoportos eloszlás különbségeit „átörökíti” a hányados mutatóba, közvetlenül (direkt módon) nem hasonlítható össze sem időben, sem térben. Ezért interpretációjakor mindig a standardhoz (a NEKIR-ben az országos átlaghoz) kell viszonyítani a halálozási/rosszindulatú daganatok miatti kockázatot.

\section{A NEKIR-ben az SH mutatók stabilizá- lására alkalmazott statisztikai mód- szerek (simító-eljárások):}

A vizsgálati populációk csökkenésével és/vagy ritka betegségek vizsgálatakor már az indirekt SH is növekvő instabilitást mutat. Nagyon kis megfigyelhető esetszám változás is extrém magas értéket eredményezhet, valamint a becslés statisztikai bizonytalansága is nagy lesz.

A fentiekhez hasonlóan az egyik lehetséges, legegyszerúbb stabilizálási mód, hogy a mutatókat időben aggregáltan (több évre összevonva) határozzuk meg, ezzel növelve a vizsgálatba bevont népesség nagyságát és a várt esetek számát. Ezt alkalmaztuk megyei és járási szinten is. 
További alkalmazott stabilizálási módok a Bayes-i statisztikán alapulnak, melyek az indirekt standardizált hányados simított becslését eredményezik'2,13,14,15,16,17. A SH bizonytalanságát is figyelembe vevő eljárások során a korrekció abban az esetben a legnagyobb, amikor az SH a leginstabilabb (pl. várható esetek száma alacsony).

A szerzők alacsony esetszámok esetén (20-nál kisebb esetszám esetén már javasolt, de 10 alatt mindenképpen a Bayes becsléssel) korrigált mutató alapján történő elemzést ajánlják.

Az empirikus Bayes becslés lényege, hogy az értékeket a teljes vizsgált terület átlagához közelíti, oly módon, hogy ez a korrekció annál nagyobb, minél instabilabb a hányados (pl. kis populáció, kis esetszám esetén)12. A korrekciós tényezőket a becslés a vizsgálati adatsorból határozza meg. Segítségével értelmezhető a kockázat az olyan területeken is, ahol nem volt megfigyelt esetszám. A NEKIR megyei szinten tartalmaz empirikus Bayes becsléssel korrigált mutatókat.
A teljes (hierarchikus) Bayes becslés ${ }^{13}$ egy komplexebb és flexibilisebb statisztikai eljárás, mely során számos más, akár nem mért tényező is figyelembe vehető. Így lehetséges e módszerrel figyelembe venni a kockázatok térbeli elrendeződését, eloszlását is, és így a stabilizálás során a teljes vizsgált terület átlagához való simítás mellett a helyi átlagokat is figyelembe lehet venni. A simítás, stabilizálás során kapott eredmények térképes ábrázolásával könnyebben azonosítható a magas kockázattal rendelkező lakosságok területi eloszlása.

A járási táblázatokban szereplő „valószínűség" megmutatja, hogy az adott területen az adott betegségcsoport miatti halálozás, megbetegedés mekkora valószínűséggel tér el az országos szinttől. Szabályként elfogadható, hogy amennyiben az érték nagyobb, mint 0,9, vagy kisebb, mint 0,1, akkor nagy valószínűséggel kizárható a véletlen szerepe, és az eltérés szignifikánsnak mondható. A térképeken az országos átlagtól szignifikánsan eltérő területek pontozással jelöltek ${ }^{16}$. 
Megjegyzendő, hogy a NEKIR-ben jelenleg települési szinten csak a területi egyenlőtlenségeket bemutató térképek érhetők el, az adatok nem.

\section{Az idöbeli alakulás vizsgálata}

A népmozgalom eredményeinek bemutatása esetszámok és intenzitási viszonyszámok segítségével történt évenként, a 2007-2018. időszakra vonatkozóan.

Megyei és országos szinten a halandóság és a daganatos megbetegedések időbeli alakulásának elemzéséhez, a halálozási/megbetegedési mutatók torzítatlan összehasonlítása érdekében, az 7-3. táblázatban felsorolt konkrét betegségcsoportok vonatkozásában Standardizált Halálozási Arányszámok (SHA) kerültek alkalmazásra 2007-tôl. Az indexek számítása a direkt standardizálás módszerét alkalmazva történt. E korrekciós statisztikai technika a korösszetételi különbségek torzító hatását kiszűri, lehetővé téve különböző népességek halálozási/megbetegedési előfordulásainak közvetlen összeha- sonlítását, és így az időbeni változások vizsgálatát ${ }^{28}$. Két standard alkalmazásával is kiszámításra kerültek a mutatók: egyik esetben standardnak tekintettük az Európai standard populáció 2013. évi, másik esetben az 1976. évi [0-14, 1-14, 1524, 0-X (0-74), 25-64, és 65-x éves korú lakosságának] kormegoszlását ${ }^{18}$.

Járási szinten a kisebb létszámú népesség és az alacsony esetszámok miatti éves ingadozásokból származó statisztikai bizonytalanságok kezelésére az eredmények stabilizálása indirekt standardizált mutatók hierarchikus Bayes-i tér-idö elemzése segítségével történt ${ }^{14,15}$. A módszerrel lehetőség van egyszerre tér és idő elemzést végezni (lásd járási szintű trendvizsgálat). Az adott évi halálozási/megbetegedési hányadosok meghatározásához minden esetben az öszszevont teljes vizsgálati időszak országos korspecifikus arányszámai szolgáltak standardként (indirekt standardizálás). Az elemzés során kapott évenkénti halálozási kockázatok jól mutatják az adott halálozás/megbetegedés tendenciáját. A táblázatban feltüntetett „valószínűség” azt mutatja meg, mekkora a valószínúsé- 
ge annak, hogy az adott halálozás/megbetegedés szignifikánsan eltér az adott év országos halálozási/megbetegedési szintjétől. Ha az érték nagyobb, mint 0,9, vagy kisebb, mint 0,1 , akkor nagy valószínúséggel kizárható a véletlen szerepe, az eltérés szignifikánsnak mondhatóit. Az összehasonlításhoz, és a trendek vizsgálatához segítségül az országos kockázatok éves értékei is elérhetőek.

Gyermekkorú daganatos megbetegedések esetén a megyei táblák is tartalmaznak tér-idő elemzéssel készült időben is stabilizált mutatókat. A népmozgalmi mutatók esetén pedig járási szinten a csecsemőhalálozási arányszám helyett szintén a tér-idő térképezéssel korrigált, simított becsült arányszám került publikálásra.

Az adatfeldolgozások és elemzések során alkalmazott szoftverek: Rapid Inquire Facility ${ }^{19}$, R-inla ${ }^{17}$, ArcGIS $^{20}$, STATA $^{21}$.

\section{Módszertani segédanyagok, kommu- nikáció}

A rendszerben használt egységes ter- minológia, az alkalmazott epidemiológiai mutatók és értékelésük, valamint értelmezésük ismerete elengedhetetlen a NEKIR felhasználók számára. Éppen ezért feldolgozott mutatók rendelkezésre bocsátásán túlmenően a Népegészségügyi Elemzési Központ folyamatosan biztosított szakmai támogatást a felhasználók számára: egyrészt a honlapon található "Módszertani útmutató"1 és „Bemutató"22 segítségével, melyek segítik a felhasználót a mutatók megértésében és módszertanilag helyes interpretálásában, másrészt a gyors, közérthető tájékozódást segítő "Gyakran ismételt kérdések (GYIK)"23 összefoglalóval.

További támogatást jelentett, hogy a Népegészségügyi Elemzési Központ munkatársai a regisztrált felhasználók körében tapasztalt eltérő tudásszint kiegyenlítése érdekében képzéseket tartottak, továbbá személyes kapcsolatfelvételen keresztül informatikai, technikai, módszertani konzultációkkal segítették a felhasználást. 
A NEKIR-ről elkészült infógrafika az érdeklődők számára közérthető formában összegzi a rendszerről szüksé- ges információkat, a rendszerben fellelhető adattartalmakat, valamint azok felhasználási lehetőségeit (6. ábra).

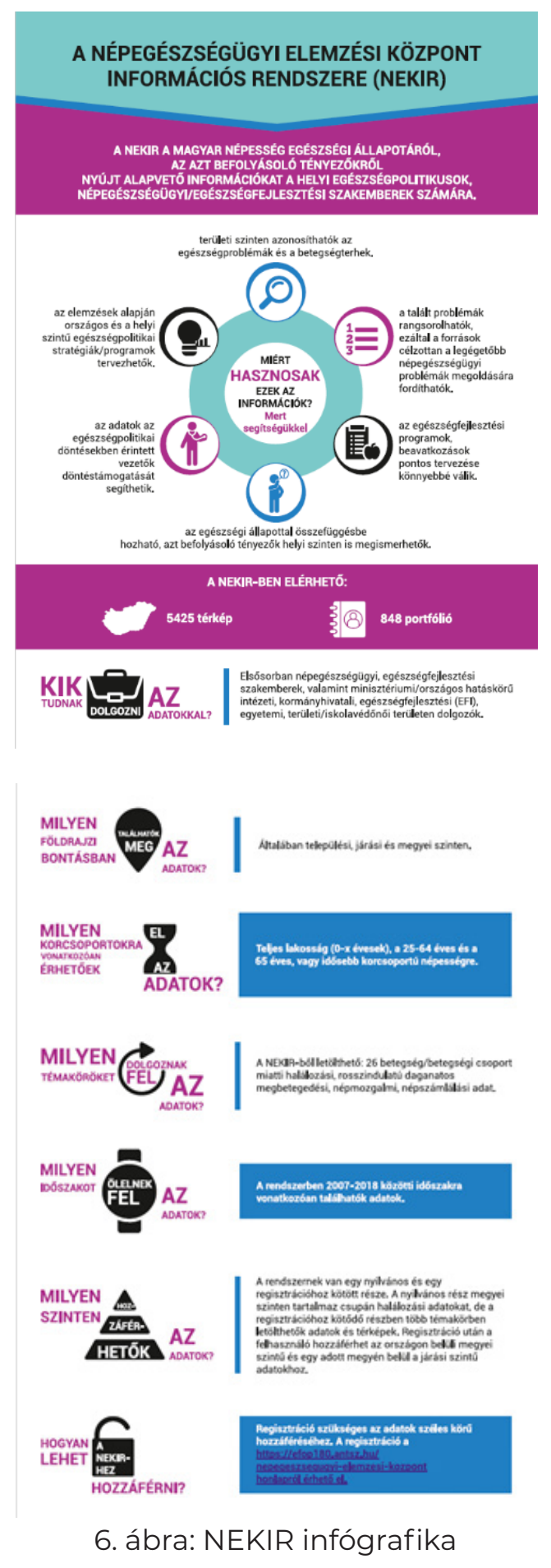

Figure 6. NEKIR infographics 


\section{A rendszer \\ információihoz történő hozzáférés}

Az „Egészségügyi ellátórendszer szakmai módszertani fejlesztése" elnevezésü projekt (https://efopl80.antsz. hu/) és a Népegészségügyi Elemzési Központ kezdőlapjáról (https://efop180. antsz.hu/nepegeszsegugyi-elemzesi-kozpont.html) közvetlenül is eljuthat a látogató a NEKIR-hez, melynek van egy nyilvános és egy regisztrációhoz kötött része.

A nyilvános rész megyei szinten tartalmaz halálozási adatokat a teljes (0-X éves) és a 25-64 éves lakosság vonatkozásában. A halálozási mutatók az általános (összes halálok miatti) halálozás, valamint a vezető haláloki főcsoportok (keringési rendszeri betegségek, rosszindulatú daganatok, emésztőrendszeri betegségek, légzőrendszeri betegségek és a külső okok) miatti halálozás tekintetében érhetők el.

A regisztrációhoz kötött részen a felhasználó hozzáférhet a 2. fejezet- ben bemutatott részletes tartalmakhoz - azaz a NEKIR moduljaihoz - azokon belül pedig megyei szintű, és egy adott megyén belül a járási szintű adatokhoz, térképekhez is.

A regisztráció a https://efop180. antsz.hu/nekinfreg címen lehetséges.

\section{A NEKIR használatának monitorozása és értékelése}

A rendszer 2019. április 5-én kezdte meg működését. Kezdetektől igény volt a rendszer tartalmának felhasználási/ felhasználói monitorozására. A felhasználók monitorozásával az volt a célunk, hogy azonosítsuk a rendszerbe regisztrált felhasználók működési területe alapján esetlegesen előforduló területi egyenlőtlenségeket, továbbá a regisztrált felhasználók rendszerhasználati szokásainak eltéréseit. Az eredmények visszacsatolásra kerülnek a további NEKIR fejlesztési igények meghatározásába. 
2019. április 5.-2020. június 30. között a rendszernek 279 különböző (minisztérium/országos hatáskörű intézet, kormányhivatalok, egészségfejlesztési irodák $\{E F \mid\}$, egyetemek, területi/iskolavédőnő, egyéb) területen dolgozó regisztrált felhasználója volt, és 74\%-uk (207 fö) aktívan használta is a rendszert. tési Iroda közel kétharmada regisztrált, de csak 43\%-a használta a rendszert. A kormányhivatali és az egyetemi felhasználók 80\%-a nemcsak a regisztrációig jutott, hanem belépett és információkat töltött le (6. táblázat), azaz a vizsgált idő alatt aktívan használta a rendszert (7. ábra).

A jelenleg működő 120 Egészségfejlesz-

6. táblázat: A NEKIR regisztrált felhasználóinak megoszlása intézménytípusok szerint, 2019. április 5.-2020. június 30.

Table 6. Distribution of registered users of NEKIR by type of institution, 5 April 2019 - 30 June 2020.

\begin{tabular}{lcc|}
\multicolumn{1}{c}{ Intézmény típus } & Regisztráltak száma & $\begin{array}{c}\text { Aktív felhasználók } \\
\text { száma }\end{array}$ \\
\hline Kormányhivatal & 87 & 70 \\
Minisztérium/országos hatáskörű intézet & 78 & 57 \\
\hline EFI & 73 & 52 \\
\hline Egyetem & 25 & 20 \\
\hline Területi /iskolai védőnő & 8 & 4 \\
\hline Egyéb & 8 & 4 \\
Összesen & 279 & 207
\end{tabular}




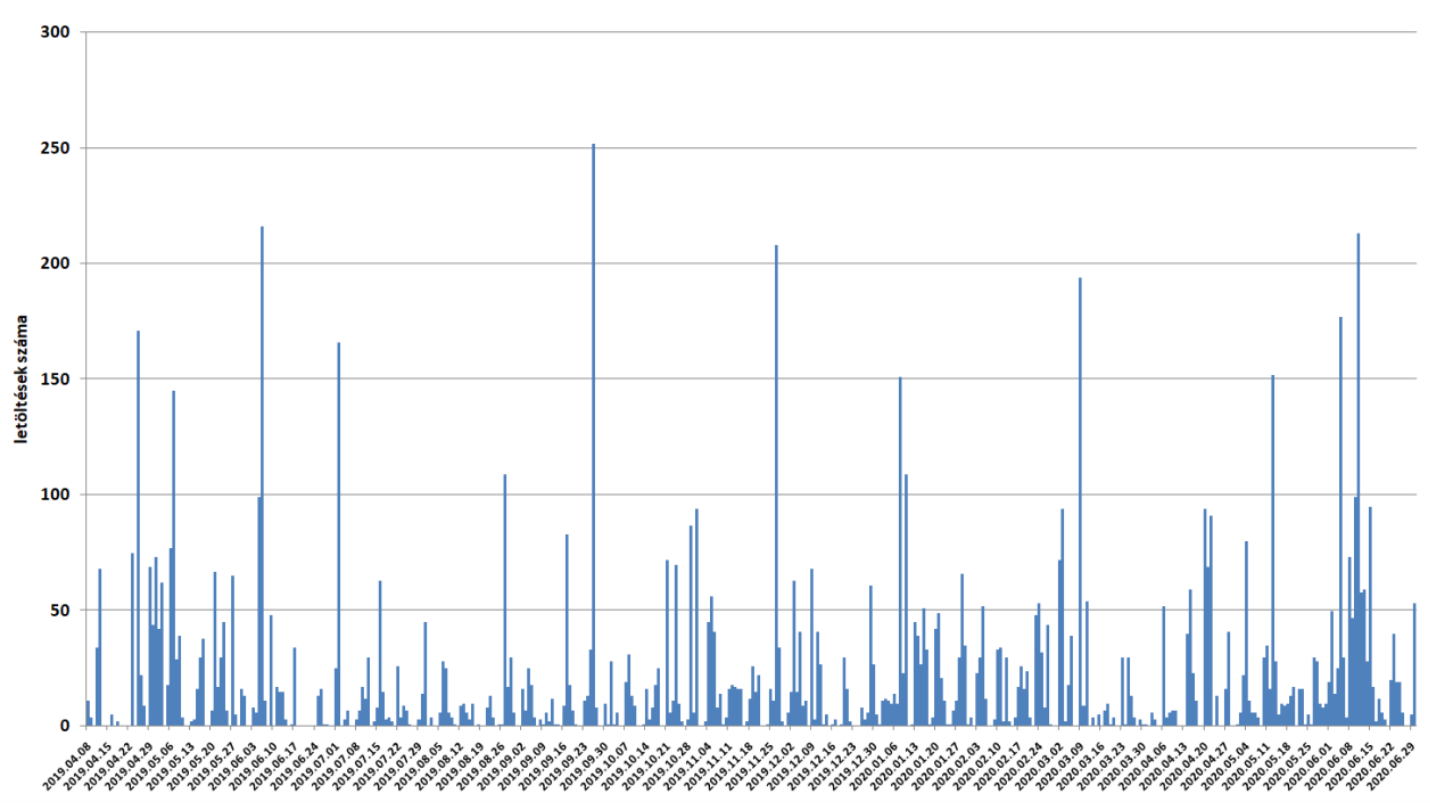

7. ábra: A napi letöltések száma a NEKIR rendszerböl 2019. április 8. és 2020. június 30. között Figure 7. Number of daily downloads from the NEKIR system between 8 April 2019 and 30 June 2020

2019. áprilisa és 2020. június vége között összesen 9.045 letöltést (napi szinten átlagosan 20 letöltést) regisztráltunk (7. ábra). Ennek döntő része (7.370, 81\%) a regisztrációhoz kötött tartalom letöltése volt, azon belül is 5.330 (72\%) térkép, 1.453 (20\%) profiltáblázat és 587 (8\%) info-profil diagram letöltése történt meg (7. táblázat).
A használat változó mintázatot mutatott munkahelyek, egyes modulok, térkép-típus és indikátorok/indikátorcsoportok szerint. Bár a regisztrált felhasználók között a kormányhivatali dolgozók közel azonos megoszlással voltak jelen, mégis közel 4-szer annyi tartalmat töltöttek le, mint az EFI, és mintegy 2,5-szer annyit, mint a központi intézményekben dolgozó munkatársak (7. táblázat). 
Összefoglaló / Továbbképző közlemény - Review / Educational article

7. táblázat: A NEKIR tartalomletöltések száma, tartalom és a felhasználó intézménytípusa szerint, 2019. április 5.-2020. június 30.

Table 7. Number of downloads from NEKIR by content and type of institution, 5 April 2019 - 30 June 2020.

Intézmény típus

\begin{tabular}{|c|c|c|c|c|}
\hline Intézmény típus & $\begin{array}{l}\text { Diagram } \\
\text { (infóprofil) }\end{array}$ & Adattábla & Térkép & Összesen \\
\hline Nyilvános letöltés & & 631 & 1044 & 1675 \\
\hline Kormányhivatal & 171 & 701 & 3384 & 4256 \\
\hline Minisztérium/országos hatáskörü intézet & 312 & 490 & 868 & 1670 \\
\hline EFI & 59 & 149 & 948 & 1156 \\
\hline Egyetem & 45 & 110 & 129 & 284 \\
\hline Egyéb & & 3 & 1 & 4 \\
\hline Összesen & 587 & 2084 & 6374 & 9045 \\
\hline
\end{tabular}

A halálozási profilok és térképek letöltése (az összes 78\%-a, 7.060 letöltés) volt a leggyakoribb, ezen belül is a korai (25-64 éves) halálozási mutatók térképeinek felhasználása dominált (40\%, 2.854 letöltés). A rosszindulatú daganatos megbetegedésekkel kapcsolatos letöltések 14\%, a népmozgalmi adatok 5\% és a népszámlálás letöltések pedig 3\% részaránnyal szerepeltek a vizsgált időszakban. A modulok szerinti letöltéseket a modulokban szereplő táblák, térképek száma és a modulok publikálásának ideje, frissítése is befolyásolta. A NEKIR ugyanis a halálozási és a rosz- szindulatú daganatos megbetegedési modullal indult 2019. április 5-én. Majd egy hónap múlva a Gyermekrák Regiszter, 2019. júliusában a népmozgalmi, szeptemberben a 2011. évi Népszámlálás adataival/moduljaival frissült a rendszer. Az infóprofilokkal bővült utoljára a rendszer, 2020. január elején.

Területi felbontás szerint a legygyakrabban letöltött térképtípusok a megye-járás (41\%-kal, 2.642 letöltés) felbontásúak voltak, ezt az ország-megye felbontású térképek (29\%-kal, 1.867 letöltés) követték. 
Indikátorok szerint részletesebben megvizsgálva, a leggyakrabban letöltött térképek (közel 32\%-ban) a rosszindulatú daganatok miatti halálozásokkal, azon belül is (50\%-ban) a „szürhető daganat típusokkal" kapcsolatos letöltések voltak. A komplex indikátorcsoportok, mint például az elkerülhető halálozás két csoportja és az Egészségügyi Világszervezet (WHO) által meghatározott túlzott alkoholfogyasztásra visszavezethető, illetve dohányzással összefüggésbe hozható csoportok miatti halálozásokkal kapcsolatos letöltések csupán $\mathbf{9 \%}$ körül valósultak meg, holott ezek az indikátorok a népegészségügyi szükségletek azonosításában és az arra alapozott egészségfejlesztési stratégiák kialakításában rendkívül jól használhatók.

A felhasználói monitorozás eredményei egyértelműen alátámasztják a NEKIR folyamatos használatát, hasznosságát, létrehozásának megalapozottságát és fenntartásának indokoltságát, fontosságát.

A monitorozás segítséget nyújthat a NEKIR rendszer rugalmasságának fenntartásában, indikátorfejlesztési irányok meghatározásában, továbbá a NEKIR-rel kapcsolatos továbbképzéseken az egyes modulokkal, az egyes indikátorokkal kapcsolatos oktatási tematika kialakításában is. A NEKIR használatával kapcsolatos szokások feltérképezése alapján és a rendelkezésre álló szakmai irányelvek, valamint az adatok hozzáférhetősége, validitása mentén a NEKIR tartalom a felhasználói igényekhez a továbbiakban is igazítható, bővíthető.

\section{Köszönetnyilvánítás}

A szerzők ezúton is köszönetet mondanak Dr. Horváth Judit Krisztina és Ferenczi Annamária kollégáknak az adatbeszerzésben, Szőke Katalinnak és Túri Gergelynek a NEKIR-rel kapcsolatos dokumentumok áttekintésében és korrekciójában nyújtott segítségéért.

\section{Nyilatkozat}

A szerzők kijelentik, hogy a közlemény más folyóiratban korábban nem jelent meg, és máshová beküldésre nem került. A cikk végle- 
ges változatát valamennyi szerző elolvasta és jóváhagyta, valamint hozzájárult a megjelenéshez.

\section{Szerzöi érdekeltségek}

A szerzőknek nincsenek a tartalmat érintő érdekeltségeik.

\section{Anyagi támogatás}

A NEKIR létrehozását az EFOP1.8.0-VEKOP-17-2017-00001 azonosító számú „Egészségügyi ellátórendszer szakmai módszertani fejlesztése” címü projekt „Népegészségügyi ellátórendszer és szolgáltatások fejlesztése" címü alprojekt támogatta.

\section{Szerzöi munkamegosztás}

J.A.: a NEKIR módszertani hátterének kidolgozása, statisztikai elemzés, a kézirat koncepciójának összeállítása, a kézirat megszövegezése.

N.CS:: a NEKIR módszertani hátterének kidolgozása, statisztikai elemzés, a kézirat koncepciójának összeállítása, a kézirat megszövegezése és levelező szerzőként gondozta a kéziratot.

L.M.: a NEKIR informatikai hátterének tervezése, létrehozása.

N.A.: a NEKIR Népmozgalmi adatok modulja - statisztikai elemzés, valamint egyes adatbázis-kezelési feladatok

P.Z.: a NEKIR módszertana - az indikátorfejlesztés, statisztikai elemzés

G.V.: a NEKIR kommunikációjával kapcsolatos munka.

O.B.: a NEKIR és a kézirat feletti teljes szakmai irányítás és ellenőrzés. 


\section{Irodalomjegyzék}

1. NEKIR, Népegészségügyi Elemzési Központ Információs Rendszer, Módszertani összefoglaló. (2020).

2. World Health Organization Regional Office for Europe. European health for all database (HFA-DB) [electronic resource]. https://apps. who.int/iris/handle/10665/108565 (2005).

3. A magyar lakosság egészségi állapota javításának módja. in A magyar lakosság egészségi állapota az ezredfordulón (ed. Ádány, R.) (Medicina, 2003).

4. A nem fertőző betegségek epidemiológiája. in Megelöző orvostan és népegészségtan (ed. Ádány, R.) (Medicina, 2012).

5. Nemzeti Népegészségügyi Központ. Népegészségügyi Elemzési Központ - NEKIR. https://efop180.antsz.hu/nepegeszsegugyi-elemzesi-kozpont.html (2020).

6. WHO | Monitoring the building blocks of health systems: a handbook of indicators and their measurement strategies. WHO https://www.who.int/healthinfo/systems/ monitoring/en/.

7. European Commission-EUROSTAT. European Core Health Indicators (ECHI). Public Health European Commission https://ec.europa.eu/ health/indicators_data/indicators_en (2016).
8. Indicators - Program Evaluation - CDC. https://www.cdc.gov/eval/indicators/index.htm (2020).

9. Nolte, E. \& Mckee, M. Does health care save lives? Avoidable mortality revisited. in (The Nuffield Trust, 2004). doi:10.13016/74zg-n46j.

10. Nolasco, A. et al. Preventable avoidable mortality: evolution of socioeconomic inequalities in urban areas in Spain, 19962003. Health Place 15, 702-711 (2009).

11. Avoidable mortality: OECD/Eurostat lists of preventable and treatable causes of death (November 2019 version). (2019).

12. Clayton, D. \& Kaldor, J. Empirical Bayes Estimates of Age-Standardized Relative Risks for Use in Disease Mapping. Biometrics 43, 671-681 (1987).

13. Besag, J., York, J. \& Mollié, A. Bayesian image restoration, with two applications in spatial statistics. Ann. Inst. Stat. Math. 43, 1-20 (1991).

14. Knorr-Held, L. Bayesian modelling of inseparable space-time variation in disease risk. Stat. Med. 19, 2555-2567 (2000).

15. Spatial and Spatio-temporal Bayesian Models with R - INLA I Wiley. Wiley.com https:// www.wiley.com/en-us/Spatial+and+Spatio+temporal+Bayesian+Models+wit$\underline{h+R+I N L A-p-9781118326558 .}$ 
16. Richardson, S., Thomson, A., Best, N. \& Elliott, P. Interpreting Posterior Relative Risk Estimates in Disease-Mapping Studies. Environ. Health Perspect. 112, 1016-1025 (2004).

17. Rue, H., Martino, S. \& Chopin, N. Approximate Bayesian inference for latent Gaussian models by using integrated nested Laplace approximations. J. R. Stat. Soc. Ser. B Stat. Methodol. 71, 319-392 (2009).

18. Revision of the European Standard Population - Report of Eurostat's task force - 2013 edition. https://ec.europa.eu/eurostat/web/products-manuals-and-guidelines/-/KS-RA-13-028.

19. Beale, L., Hodgson, S., Abellan, J. J., LeFevre, S. \& Jarup, L. Evaluation of Spatial
Relationships between Health and the Environment: The Rapid Inquiry Facility. Environ. Health Perspect. 118, 1306-1312 (2010).

20. ArCGIS 10.3. (ESRI, 2015).

21. StataCorp. 2013. Stata Statistical Software: Release 13. College Station. (TX: StataCorp LP).

22. Tartalom és elemzési lehetőségek - Népegészségügyi Elemzési Központ Információs Rendszer (NEKIR). https://efop180. antsz.hu/nekir-bemutato.html (2020).

23. Gyakran Ismételt Kérdések - Népegészségügyi Elemzési Központ Információs Rendszer (NEKIR). https://efop180.antsz.hu/nekir-gyik.html (2020). 